\title{
JAXA 無人機システム安全技術基準
}

\author{
石 川 和 敏*1 柳 原 正 明*2 河 野 敬*1
}

\section{JAXA's UAS Safety Technology Standard}

\author{
Kazutoshi Ishikawa*1, Masaaki Yanagihara $^{* 2}$ and Takeshi Kohno*1
}

\begin{abstract}
The Japan Aerospace Exploration Agency (JAXA) is using Unmanned Aircraft Systems (UAS) for the flight demonstration experiments which had aviation technology proof for its object, but also becomes to research and development technologies aiming at practical use of UASs. In order to put such demonstration experiments into effect safely and use, JAXA has settled a UAS Safety Technology Standard and has been licensing safety reviews to all UAS research and development projects of JAXA.

This paper reports the outline of the JAXA's UAS Safe Technical Standard and results of safety ensuring in demonstration experiments based on the standard.
\end{abstract}

Key Words: Unmanned Aircraft Systems (UAS), Safety Technology Standard

\section{1.は じめに}

日本において産業用小型無人航空機は農業用などを中心とし て広く利用されてきたが, 安全性, 特に墜落等が発生した場合 の地上の人に対する安全性を確保する技術が確立していないこ とから，その運用は主に無人地帯の上空に限定されてきた。ま た, 最近ではドローンと通称されるマルチロータ型小型無人機 が容易に入手，ホビーや産業にかかわらず運用できる状況になっ ており, 利用人口や飛行領域の急速な拡大に伴って, 安全の確 保が喫緊の社会問題となっている.

航空法では航空機の定義を「人が乗つて航空の用に供するこ とができる飛行機, 回転翼航空機, 滑空機及び飛行船その他政令 で定める航空の用に供することができる機器 (航空法第 2 条)」 としており, 小型無人機は原則として航空機とは見なされず（機 体規模の大きいものは「無操縦者航空機 (航空法第 87 条)」と して扱われるケースがある)，「飛行に影響を及ぼすおそれのあ る行為（航空法第 99 条の 2)」としての法令に従う限りは航空法 等による規制を受けることはなかった（2015 年 12 月 10 日施行 の航空法改正により無人航空機の飛行方式等が追加された). し たがって, 無人機の運用においては法令の遵守以外の方法で, 特 に運用空域下の第三者に対する安全性を保証する必要があった。 国立研究開発法人宇宙航空研究開発機構（以下，JAXA）で

原稿受付 2016 年 1 月 29 日

${ }^{* 1}$ 国立研究開発法人宇宙航空研究開発機構

$* 2$ 国立大学法人信州大学

${ }^{* 1}$ Japan Aerospace Exploration Agency

${ }^{* 2}$ Shinshu University

口本論文は有用性（実証実験分野）で評価されました。
は航空技術の実証等を目的とした飛行試験のために無人機を積 極的に利用してきた。 また最近では無人機の実用化を目指した 技術開発を行い，その実証実験等も実施している。そのような 実証実験等における無人機運用の安全性の確立のため，2009 年 にはJAXA 内部向けの安全技術基準を策定し，同基準に従った 安全審査を行っている．また，2012 年 3 月には有人地帯での無 人機運用を目的として内部安全技術基準の改訂を実施した。本 報では同安全技術基準の概要と，同基準に基づく実証試験にお ける安全確保の実績について述べる.

\section{JAXA 無人機システム安全技術基準の制定}

JAXAにおける無人機を用いた飛行実験を安全, 確実に実施 する目的で，複数の技術部門，安全管理部門を横断した無人機 システム安全専門部会を設置して検討を行い，2009 年 3 月に 「無人機システム安全技術基準（JERG-5-001）」を制定して無 人機の設計，運用における安全基準を明確化した。この規定は small 機（最大離陸重量 $0.2[\mathrm{~kg}] \sim 150[\mathrm{~kg}]$ の無人機）, large 機 （最大離陸重量 $150[\mathrm{~kg}]$ 以上）の 2 種類の無人機について，第 三者とその財産および実験関係者の安全を確保することを目的 として，立入制限・監視により無人であることを保証した領域 の上空で運用する際の安全基準を定めたものであった.

システム等の安全設計においては，基本的に故障許容（fault tolerant）設計によることが規定されており，故障許容設計によ ることが非現実的な場合は, リスク最小化設計, 確率論的リスク 評価によることができるとしている，また，別途ハザード解析を 実施し，識別されたハザードが許容レベル以下に制御されてい ることを示すことも要求されている. 故障許容設計の指標とし 


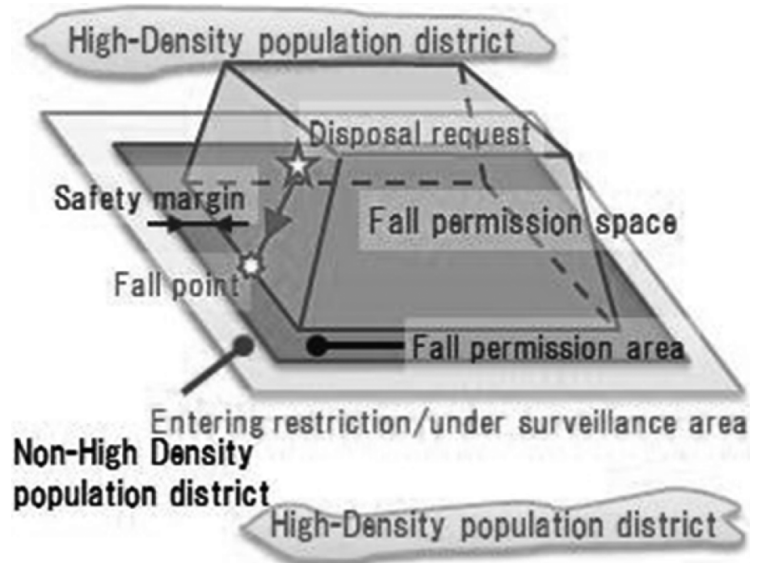

Fig. 1 Flight space request in entering restriction area

ては，原則としてカタストロフィック・ハザード（Catastrophic Hazard）に対しては，2 故障許容設計，クリティカル・ハザー ド（Critical Hazard）に対しては，1故障許容設計とすること となっている.

飛行空域への要求としては, まず第三者の立入を制限, または 監視により内部に第三者がいないことが確認できる領域を立入制 限・監視区域 (Entering restriction/under surveillance area) として設定し，それに包含されるように機体落下許容区域（Fall permission area）を設定すること, そのうえで, 飛行中にど の場所で不具合等が発生しても機体落下許容区域内に安全余裕 (Safety Margin) をもって機体が落着（Fall/landing）するよ うに飛行空域（Fall permission space）を設定することが求め られている（Fig. 1). 設定に当たっては，自治体，海上保安庁， 国土交通省等，当該区域・空域の管理者の了解を取ることが必 要である.

実施体制については，操縦者と別に実験全体の実施責任者を 置くこと,さらに実施責任者とは別に安全に関する判断を行う 安全管理主任を置き, 安全に関する判断については実施責任者 よりも安全管理主任の判断を優先すること, 必要に応じて安全 監視者を配置すること等が要求されている.

その他として, 法令順守, 品質保証, 保守, (操縦) 資格, 教 育訓練，保管管理および廃棄に対する要求を定めている，本基 準を用いて設計・運用を行う者が原則 JAXAに限られること, 対象となる無人機システムが多種多様であることを考慮し, こ れらの要求は一般的なものに留めている.

\section{3. 無人機システム安全技術基準の改訂}

小型無人機の有用性を実証するために実運用を想定した広範 な地域で飛行実証を行いたいという要求があり, その実験飛行 では 2 章で述べた安全基準で想定しているように全飛行空域下 の領域を立入制限，監視下に置くことは困難であった。このよう な有人地帯における飛行試験の要望に対応するため無人機シス テム安全専門部会において引き続き検討作業を行い，まず small 機（最大離陸重量 $0.2[\mathrm{~kg}] \sim 150[\mathrm{~kg}]$ ）について有人地带の非高 密度地帯（第三者が日常的に居住している住居等の施設があっ てもまばらであり, かつ人や車両, 船舶の往来があっても稀であ
る区域, Non-High-Density population district）上空で飛行 する際の安全基準を追加し, 無人機システム安全技術基準の $\mathrm{A}$ 改訂（JERG-5-001A）として 2012 年 3 月に発行した [1]（以 下，追加部分を「増補版」と記す)，増補版においては，海外の 事例等 [2] [3] も参考にしつつ, 設計基準として構造系, 推進系, 地上管制系, 通信系, 飛行安全系に関する要求が, また運用基 準他として空域の設定, 飛行計画, 運用手順, 保守に関する要 求がそれぞれ追加，または従来基準から改訂されている．以下 に主要な改訂内容を記す.

\section{1 設計基準に関する増補版要求}

a) 構造系

従来基準においては想定される飛行状態の荷重，振動に十分 な余裕を持って耐えられることのみが規定されていたが，これ を具体化，明確化するための改訂が行われた.

内容としては, 主翼, 主翼取付部, 後部胴体の基本構造が終 極荷重に耐えられることを試験あるいは解析により証明するこ と, 疲労荷重については, 想定される運用中の荷重が疲労限に 対し余裕があることを示すか, 典型的な飛行パターンについて 計画飛行回数に相当する疲労強度試験により実証することが求 められている．終極荷重としては制限運動荷重倍数 $3.8[\mathrm{G}]$ を 基本とし, 高機動機については想定される最大值を用いること, 風洞試験等により荷重倍数が最大揚力係数により制限されるこ とが示せる場合は空力的に負荷できる $3.8[\mathrm{G}]$ 未満の倍数を用 いることが認められている．また規定の垂直突風荷重を考慮す ることが求められている. さらに, 強度試験を実施し, 制限荷 重に対し有害な変形を生じないこと, 終極荷重に対し最低でも 3 秒間耐えられることが求められている.

b) 推進系

従来基準ではシステム仕様書への要目記載, 燃料または電力 管理が求められていたが, 増補版では推進系を構成するすべて の系について，系統図を示すとともに，想定される運動モード において不具合が生じないことを証明すること，また耐空証明 を有しない推進器について所定の耐久試験を行うことが求めら れている.

c）航法, 誘導, 制御系

従来基準では制御系の一故障時も，飛行安全措置の実施が可 能であること, 視程外空域を飛行する場合は, 機体の位置を計 測できる航法装置を搭載することが規定され，また large 機に ついてのみ通常航法に使用される位置通知機能と独立な位置通 知機能をもう一式（追跡機，監視員による目視等を含む）有す ることが求められていた.

増補版では，視程外飛行を行う small 機についても同様の装 備が求められることとなっている.

d) 通信系

従来基準においては想定されるすべての運用範囲において, 安全な飛行の継続または飛行安全措置の実施に十分な電波リン クが確保できること. 電磁干渉対策がとられ, 事前に試験等で 検証されていることが規定されており，また large 機について は電波リンク設計にかかわるリンクマージンの設定要求, およ び設定指標等の要求が示されていた，増補版では，視程外飛行 を行う small 機についても同様の要求が規定されている.また 


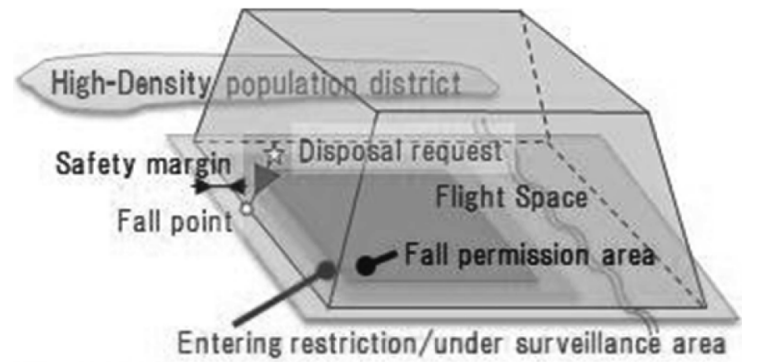

Non-High Density population district

High-Density population district

Fig. 2 Flight space in non-high-density population district

設計解析による定量確認が困難な場合は地上試験または段階的 な予備飛行試験により運用条件相当での受信確認が求められて いる.

e）飛行安全系

離陸重量 $100[\mathrm{~kg}]$ を越える機体について, 発動機停止時に被 害を押さえた不時着を可能にするため, 運動エネルギー低減機 能や滑空誘導飛行機能を要求している.

\section{2 運用基準他に関する増補版要求}

\section{a）空域の設定}

2 章で述べたとおり，従来基準では，領域内のいかなる場所 で不具合等が生じても立入制限・監視区域内に十分な安全余裕 を持って落着するように飛行空域を設定することとなっていた. これに対し, 増補版では試験目的の達成のために必須である場 合に限り

·非高密度区域の上空であること

・可能な限り安全な区域を選定すること

を条件として, 機体落下許容区域を越えて飛行空域 (Flight Space）を設定することを認めている（Fig. 2).

飛行空域は，その内部のいかなる点で機体廃棄機能が作動し ても，機体が飛行空域外に落下しないように設定すること，機 体落下時の風の影響についても考慮することを要求している. また，設定に当たっては，自治体等，利害関係が生じる可能性 が外部組織を明確にし，必要に応じてそれらの組織に十分な情 報を伝達することを要求している.

飛行区域内は，原則として管制塔・駐機場やパワープラント， 幹線道路/鉄道, 高圧電線等の第三者の重要施設を避けて設定す ることを要求している。ただし，離着陸時の極めて短時間に管 制塔などの上空を飛行せざるを得ない場合や，(車両などの往来 が十分少ない) 幹線道路/鉄道などを横断せざるを得ない場合等 は, それら施設の所有者およびその他関係者と調整のうえ, 飛 行空域に設定することを許容している.

ただし，離着陸を行う区域は，従来どおり，立入制限・監視 区域内に設定する必要がある。

b) 飛行計画

予測事故被害者数を「飛行中のある時間区間に，機体システ ム，搭載システム，もしくは地上システムの不具合に起因する 事故により発生する被害者数の予測值」として定義し，

·離陸（T/O, Take-off）～着陸（L/D, Landing）の予測事故

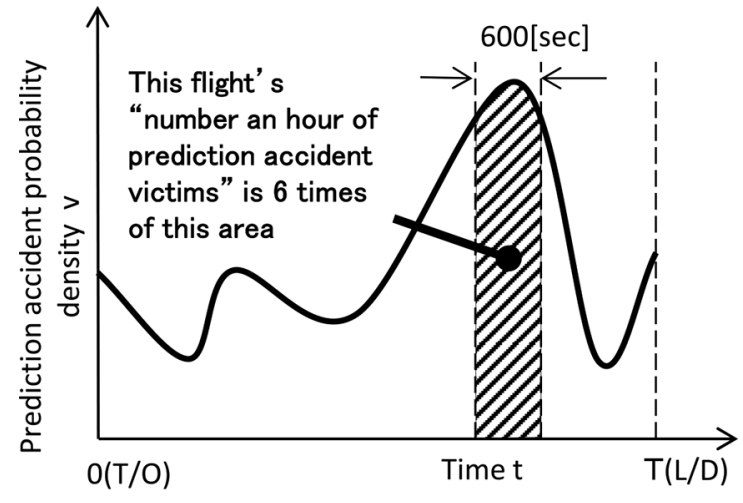

Fig. 3 Prediction accident victims

被害者数を可能な限り下げること

・単位時間当の予測事故被害者数を規定值に抑えること

を規定している.

任意の時刻 $t 1, t 2 （$ ただし $t 1<t 2 ）$ の間の予測事故被害者 数は

$$
V(t 1, t 2)[\text { 人 }]=\int_{t 1}^{t 2} v(t) d t
$$

で求められる。ここで

$v(t)$ : 予測事故被害者数密度 $[$ 人 $/ \mathrm{s}]$

であり，

$$
v(t)=f(t) \times P(t) \times(t) \times r(t)
$$

で与えられる。ここで

$f(t):$ 機体墜落確率密度 $[/ \mathrm{s}]$

$P(t)$ : 機体直下の地区の人口密度 $\left[\right.$ 人 $\left./ \mathrm{m}^{2}\right]$

$S(t)$ : 墜落時影響面積 $\left[\mathrm{m}^{2}\right]$

$r(t)$ : 墜落時事故被害率 $(0 \leqq r(t) \leqq 1)$

である。

また予測事故被害者数（Number of prediction accident victims）は時間の関数となるため，飛行時間中の任意の 10 分間 について予測事故被害者数を算出し，その最大值を 6 倍するこ とで，単位時間当たりの最大予測事故被害者数とすることにし ている（Fig. 3).

予測事故被害者数の算出に当たっては, 人口密度 $P(t)$ とし て総務省統計局の提供する $500[\mathrm{~m}]$ メッシュデータを用いるこ とを基本とするが，昼夜の人口変動，メッシュ内での人口の偏 り等を考慮することとしている.

機体墜落確率密度 $f(t)$ は機体墜落率 $\lambda(t)$ と信頼度 $R(t)$ の 積となる。 $\lambda(t)$ については解析あるいは実績により算出するこ ととしている. 信頼度 $R(t)$ は時刻 $t$ に機体が飛行している確率 を意味し， $0 \leqq R(t) \leqq 1$ となる.

機体墜落時影響面積 $S(t)$ は，機体が墜落時に地上に被害を及 ぼす区域の面積であり，機体の投影面積および落下角度を考慮 して計算することになるが，墜落時に爆発等で広域に散乱する 場合はそれを考慮する必要がある.

墜落時事故被害率 $r(t)$ は，算出または証明できない場合には 
1 を使用することになっている. 高速で重い大型機の場合は 1 とならざるを得ないが, 軽量で低速の小型機に対する墜落時事 故被害率の算出方法や評価については, 対人衝突安全性の評価 としてJAXA で研究を行っている $[6]$.

\section{4. 無人機システム安全技術基準（増補版）適用例}

4.1 災害監視無人機システム

本機構においては 2005 年より 2012 年まで災害監視を目的と した小型無人機システム（SAFE, Smart Autonomous Flying Eye, Fig. 4）の研究開発を実施してきた [5] [6]. 同事業では, 開発された無人機システムの有用性, 運用性を実証するため, 実 際の運用現場を想定した山間部で防災関係者を招いた実験を行う こととなった。この場所は, 通常開発飛行試験を行う立入制限・ 監視が可能な場所ではない山間部の河川流域である (Fig. 5). 同地域内は国勢調査による $500[\mathrm{~m}]$ 地域メッシュ統計による居 住人口は $0[$ 人] であったが, 農作業, 山林保守等の人員の立入 があり，また領域に進入するすべての道路（登山道, 歩行可能 な沢等を含む）を監視下に置くことが困難であったことから事 実上有人地带と見なして増補版を含む安全基準を適用して飛行 実験を実施した [7].

設計基準に対しては，耐荷重試験やモータ耐久試験等により， 制限・終端荷重倍数および安全余裕などを確認するとともに, 飛 行区域を逸脱させないために圥長の安全系を組み込むなどで基

\begin{tabular}{ll}
\hline Length/Wide & $1.6[\mathrm{~m}] / 2.2[\mathrm{~m}]$ \\
Weight & $5.0[\mathrm{~kg}]$ \\
Payload & Under $0.3[\mathrm{~kg}]$ \\
Altitude & Under $250[\mathrm{~m}]$ \\
Velocity & Max.90[km/h] \\
FLT time & $20[\mathrm{~min}]$ \\
Power & Electronic Motor \\
Control & Auto/(Man) \\
\hline
\end{tabular}

Fig. 4 SAFE
準との適合性を確認した。運用基準に対しては，飛行区域内に 第三者が 5 [人] 程度いると仮定した予測事故被害者数が制限值 以下となる機体墜落確率を実証するため, 立入制限・監視区域 で 10 回以上の飛行実績を積むこととした。また，山間部にお ける地形風による影響を評価するなどし, 風向・風速などの運 用制限を設定した。

同地区での飛行実験では, 21 回の飛行（うち観測飛行は 18 回）を行い, 総飛行時間は 2 時間 38 分だった.

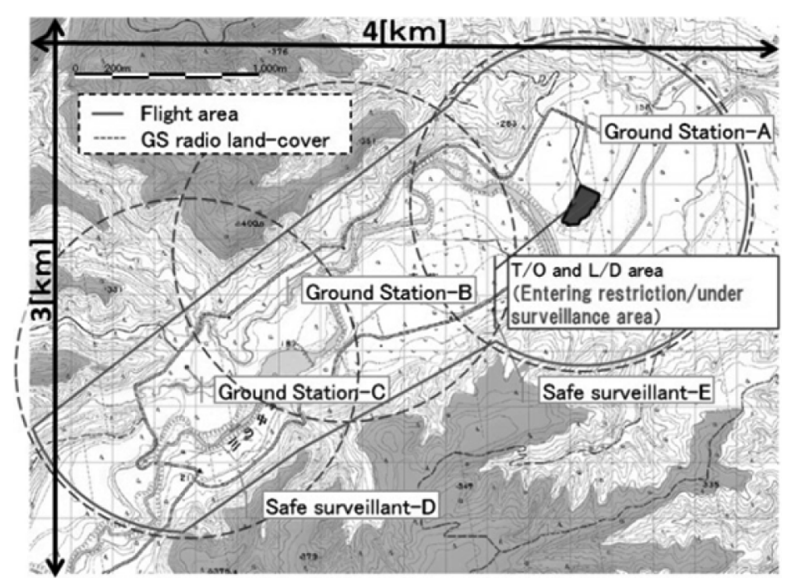

Fig. 5 SAFE's flight area

\begin{tabular}{ll}
\hline Length/Wide & $2.7[\mathrm{~m}] / 4.2[\mathrm{~m}]$ \\
Weight & Max 50[kg] \\
Payload & $3 \sim 10[\mathrm{~kg}]$ \\
Altitude & Under $250[\mathrm{~m}]$ \\
Velocity & $90 \sim 126[\mathrm{~km} / \mathrm{h}]$ \\
FLT time & $6[\mathrm{hrs}]$ \\
Power & Engine \\
Control & Auto/Man \\
\hline
\end{tabular}

Fig. 6 UARMS

\section{Design of UARMS}

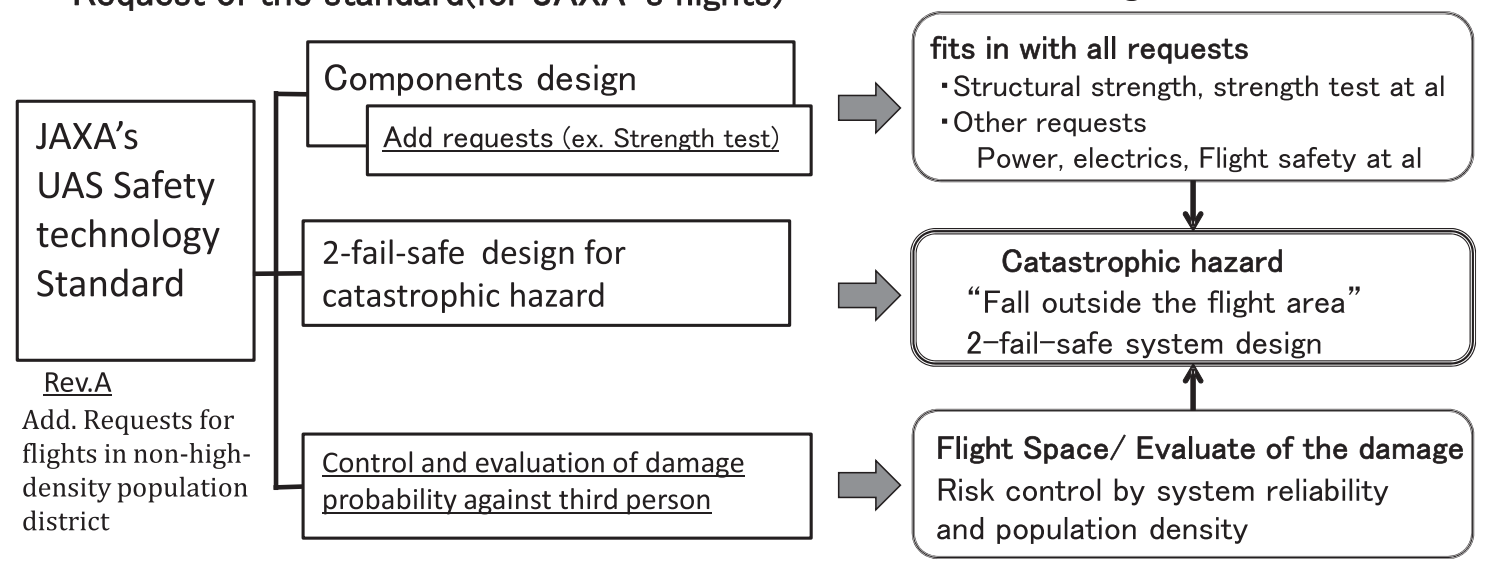

Fig. 7 Safety deign of UARMS 


\section{2 放射線モニタリングシステム}

国立研究開発法人日本原子力研究開発機構（JAEA）との共 同研究により 2012 年より実施している小型無人機による放射線 モニタリングシステムの研究開発 (UARMS, Unmanned Airplane for Radiation Monitoring System, Fig.6) において, JAEA は実用段階において福島地区の広範囲における計測飛 行を予定していた，そのため，事実上有人地帯上空の飛行が必 要になると考えられることから, 開発時より増補版を含む安全 基準を適用して設計，開発試験等を実施している [8]（Fig. 7). UARMS では，システム等にかかわるハザードを識別し，設計． 製造・試験および運用段階を通じて適切な手段によりハザードを 除去，または最小化および制御して安全を確保するため，開発初 期の段階からシステム安全プログラムを計画し，それに従い開 発の必要な段階でシステム安全審査会を実行した。 また, 開発途 中で必要となる飛行試験に対しては個別に安全審査を実施した。

予測事故被害者数に関しては，信頼度デー夕を立入制限・監 視区域内の目視内飛行試験で取得し，この信頼度データと飛行 経路上の人口密度データベースから計算される予測事故被害者 数を制限值以下となるように，実運用時の飛行経路を設定する こととしている.

\section{5. ま と め}

無人機を用いた飛行実験を安全，確実に実施する目的で，本 機構では「無人機システム安全技術基準」を制定して無人機の 設計，運用における安全基準を明確化し，それに基ついた安全 審査を事前に行うことで飛行実験を安全に実施してきた。また， 有人地帯における飛行試験を実施するため, 非高密度区域に限 定した有人地帯上空における運用を含む安全技術基準を制定し た．同基準はこれまでの無人地帯用の基準に加え，主に機体の 耐空性にかかわる条項等の追加と, 墜落時に一定の安全性を確 保するために，飛行時間ごとの予測事故被害者数を算定し，一 定值以下であることを保証することを求めるものである.

同基準を適用してこれまでに有人地帯上空を含む複数回の飛行
試験を実施した，機体の改修や運用計画の適切な設定により，有 人地帯上空も含めた飛行実験を安全基準に従って実施してきた.

2015 年 4 月に発生した首相官邸へのドローンの侵入に伴って 政府による法規制整備の動きが加速した結果，制定された改正 航空法等に対して整合するように，本安全技術基準を改訂して いく必要がある. 政府による安全基準の骨子 [9] は小型無人機が 飛行しても良い場所，飛行方法に相応の制限を課す一方で，安全 を立証することによりその制限を緩和してく方針を打ち出して いる．同骨子では今後は関係者等との調整を行いながら無人機 の安全運用ための制度設計を進めていくこととしており，その中 で小型無人機の利用領域を特に有人地帯上空に拡大していくた めに，本安全技術基準，および本基準を適用して実施してきた飛 行試験の実績が少しでも寄与することを期待するものである.

\section{参 考 文 献}

[1] M. Nakadate: JAXA's UAS Safety Requirements for Flight over Populated Areas-With Emphasis on Airworthiness-, UAS International, 2012.

[2] FAA Order 8130.34: Airworthiness Certification of Unmanned Aircraft Systems and Optionally Piloted Aircraft, Federal Aviation Administration, 2012.

[3] NATO STANAG4671: Unmanned Aerial Vehicle System Airworthiness Requirement, North Atlantic Treaty Organization, 2011.

[4] 平林，ほか：“㷋害監視無人機システムの研究開発一小型無人機の対 人衝突安全の評価—”，第 51 回飛行機シンポジウム， $2 \mathrm{~F} 10,2013$.

[5] 原田, ほか：“災害監視無人機システムの研究開発—システムコンセ プトと実証実験—，第 51 回飛行機シンポジウム，2F06，2013.

[6] 石川, ほか: “災害監視無人機システムの研究開発一無人飛行機シス テム概要—”, 第 51 回飛行機シンポジウム，2F07，2013.

[7] 河野, ほか：“災害監視無人機システムの研究開発一有人地帯上空で の運用を目指した安全性の検討—”, 第 51 回飛行機シンポジウム, 2F09, 2013.

[8] 村岡，ほか：“放射線モニタリング無人飛行機の研究開発”, 第 52 回 飛行機シンポジウム, 3B09, 2014.

[9] 小型無人機に関する安全・安心な運航の確保等に向けたルールの骨子, 小型無人機に関する関係府省庁連絡会議，2015.06.02

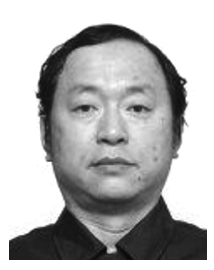

石川和敏（Kazutoshi Ishikawa）

国立研究開発法人宇宙航空研究開発機構 (JAXA) 航空技術部門次世代イノベーションハブマネージャ。 1985 年科学技術庁航空宇宙技術研究所（現 JAXA） 入所. インフライトシミュレータ「MuPAL」, 自動 着陸実験機「ALFLEX」，災害監視無人機システム などの研究開発に従事. 2012 年より JAXA 無人機 システム安全専門部会代表. 2015 年 4 月より現職. 専門は計測制御, 飛行実験。日本航空宇宙学会会員.

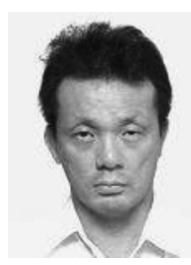

\section{河野 敬（Takeshi Kohno）}

国立研究開発法人宇宙航空研究開発機構 (JAXA) 航空技術部門航空技術実証研究開発ユニットセク ションリーダ. 1993 年科学技術庁航空宇宙技術研 究所（現 JAXA）入所．成層圈プラットフォーム飛 行船, 災害監視無人機システム, 無人航運航術など の研究開発に従事. JAXA 無人機システム安全専 門部会委員. 2015 年 4 月より現職. 専門は飛行制御，運航技術. 日 本航空宇宙学会会員.

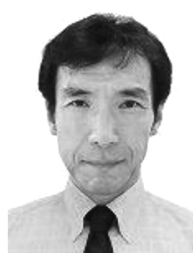

柳原正明（Masaaki Yanagihara）

国立大学法人信州大学工学部特任教授，国立研究 開発法人宇宙航空研究開発機構特任担当役. 1981 年科学技術庁航空宇宙技術研究所（現 JAXA）入 所，短距離離着陸実験機「飛鳥」，宇宙往還技術試 験機「HOPE-X」などの研究開発に従事. 2005 年 JAXA 総合研究本部飛行試験技術開発センター長, 2005 年より 2012 年の間 JAXA 無人機システム専門部会代表, 2014 年航空技術部門基盤技術統括，2016 年 4 月より現職。専門は飛行制 御, 飛行力学. 工学博士. 日本航空宇宙学会, 米国航空宇宙学会会員. 